\title{
Evaluation of Roadside Wrong-Way Warning Systems with Different Types of Sensors
}

\author{
Jian Xing
}

Nippon Expressway Research Institute Co. Ltd., Machida, Tokyo 194-8508, Japan

\begin{abstract}
Driving the wrong way on motorways has been a nagging traffic safety problem all over the world. In order to reduce wrong-way driving incidents and crashes, roadside wrong-way warning systems applying advanced ITS (intelligent transportation systems) technologies have been adopted and deployed for the first time at 24 rest areas on motorways in Japan since 2008 . The systems are used to detect wrong-way vehicles and warn the drivers of their wrong-way driving at the off-ramps to the rest areas. This paper describes an evaluation of the roadside wrong-way warning systems with four different types of sensors from the viewpoint of detection accuracy and effectiveness in preventing wrong-way driving. The sensing technology includes microwave Doppler radar, ultrasonic sensor, photoelectric sensor and video image processing technology.
\end{abstract}

Key words: Wrong-way driving, wrong-way crash, wrong-way warning system, safety, motorway.

\section{Introduction}

Drivers who make wrong-way entries onto motorways or other access-controlled highways pose a serious risk to the safety of themselves and other motorists. Wrong-way driving often leads to severe head-on crashes on motorways. Wrong-way crashes are relatively infrequent, but they are more likely to cause fatalities and serious injuries compared with other types of motorway crashes. Driving the wrong way on motorways has been a nagging traffic safety problem all over the world. Although some engineering efforts have been made and measures taken to reduce wrong-way driving and related crashes, the problem persists partly because most wrong-way driving incidents that have not resulted in crashes were not reported, and thus, wrong-way crash data is very limited for analysis.

Most studies have analyzed wrong-way crashes that had occurred in the United States and some European countries [1-6]. Few studies, however, have been conducted to uncover the characteristics of

Corresponding author: Jian Xing, Dr., research fields: traffic, transportation engineering and ITS (intelligent transportation systems). wrong-way crashes that occurred on motorways in Japan $[7,8]$.

According to the author's preceding study [7], more than 900 wrong-way incidents were reported to occur annually on entire inter-city motorway network in Japan between 2005 and 2009, and of them, nearly $3 \%$, or nearly 30 incidents, ended in crashes. And of the total 133 wrong-way crashes that occurred in the five years, half (67 crashes) involved casualties and $15 \%$ (20 crashes) resulted in fatal accidents, each being much higher when compared with all types of crashes with $13 \%$ for crashes causing death and injury and $0.5 \%$ for fatal crashes. Looking into the origination of wrong-way driving, nearly $40 \%$ of vehicles in wrong-way crashes took U-turns on the mainline, followed by $20 \%$ entering the wrong way at interchanges after passing the tollgate, $18 \%$ before passing the tollgate, and $12 \%$ at rest areas. Wrong entries and suspected dementia were the two main contributing factors for wrong-way crashes, each accounting for nearly $30 \%$ of the total number of crashes.

In order to reduce wrong-way driving incidents and wrong-way crashes on motorways in Japan, 
conventional highway traffic control devices such as "DO NOT ENTER" signs, pavement arrow markings, other wrong-way warning signboards and rubber post partial dividers have been applied on ramps at interchanges, junctions and rest areas, which have also been taken in others countries $[1-4,9,10]$. In addition, three types of wrong-way warning systems applying advanced ITS (intelligent transportation systems) technologies have been adopted and deployed recently $[7,8]$. They are the roadside wrong-way warning system with different types of sensors, autonomous wrong-way driving alert system using GPS (global positioning system) and digital map, and wrong-way warning system with road-to-vehicle communications such as DSRC (dedicated short-range communications).

This paper describes an evaluation of the roadside wrong-way warning systems with different types of sensors that were applied for the first time in 2008 at 24 rest areas on motorways in Japan, from the viewpoint of detection accuracy and effectiveness in preventing wrong-way driving. The sensing technology includes microwave Doppler radar, ultrasonic sensor, photoelectric sensor and video image processing technology.

\section{Outline of the Roadside Wrong-Way Warning Systems}

As a pilot project, several roadside wrong-way warning systems with different types of sensing technology were implemented as a first trial in Japan at the off-ramps of 24 rest areas on Japanese motorways in 2008. They are large-scale applications so far compared to the similar ones conducted in other countries $[1-4,11,12]$. The system consists of sensors for detecting wrong-way vehicles, a roadside VMS (variable message sign) or signboard displaying messages such as "Wrong way!" or "Stop!" or "Do not enter!", and flashing lights or rotating lamps or even speakers to attract the driver's attention (Fig. 1). The systems are used to detect wrong-way vehicles and warn the drivers of their wrong-way driving at the off-ramps to the rest areas. Once the system detects a vehicle going the wrong way, it will also activate a video system and record the incident one minute each before and after the detection of wrong-way vehicle. The system automatically outputs the number of wrong-way vehicles and the two-minute video images of each wrong-way vehicle detected. The two-minute video images are later used to check if the detection of wrong-way driving is correct or not, and whether the wrong-way vehicle stopped going the wrong way and turned back to the rest area in response to the warnings from the roadside wrong-way warning system. These data are used to examine the detection accuracy and prevention effect of the system.

Table 1 describes the characteristics of the roadside wrong-way warning systems with four different types of sensors which were installed at 24 rest areas on motorways across Japan. The sensing technology includes microwave Doppler radar, ultrasonic sensor, photoelectric sensor and video image processing technology. The ultrasonic and photoelectric sensors detect wrong-way vehicles from the time the vehicles

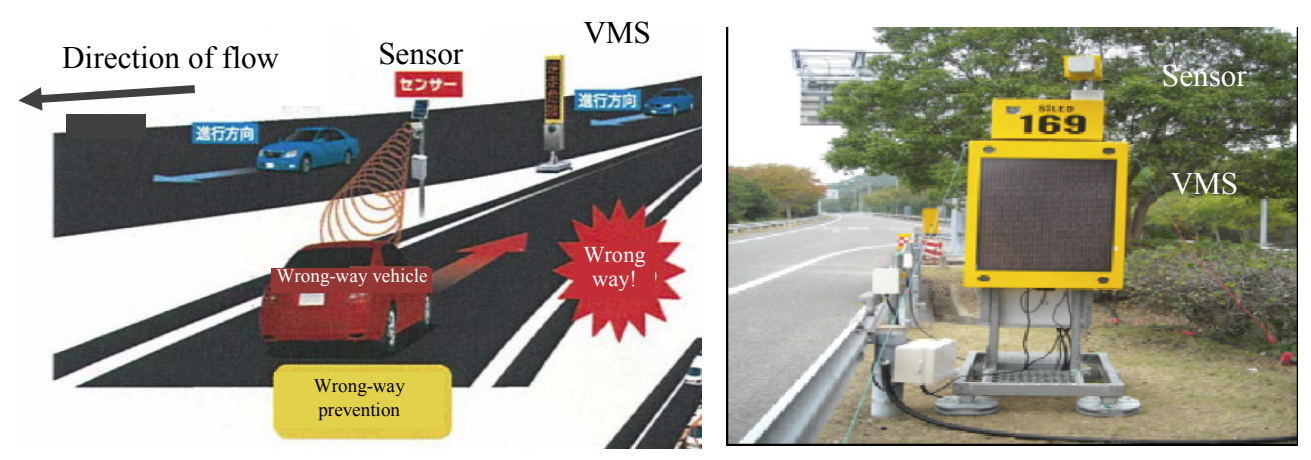

Fig. 1 Roadside wrong-way warning systems with different types of sensors. 
Table 1 Characteristics of the roadside wrong-way warning systems with different types of sensors.

\begin{tabular}{|l|l|l|l|l|}
\hline Sensor type & Ultrasonic sensor & Microwave Doppler sensor & Video image processing sensor & Photoelectric sensor \\
\hline \# of sensors & 2 & 1 & 1 & 2 \\
\hline Sensor spacing & $2.8 \mathrm{~m}$ & - & - & $0.5 \sim 1.0 \mathrm{~m}$ \\
\hline Detection range & $0.5 \sim 5.0 \mathrm{~m}$ & $\begin{array}{l}100 \sim 200 \mathrm{~m}(\mathrm{M}-2) ; \\
2 \sim 15 \mathrm{~m}(\mathrm{M}-3) ; \\
50 \sim 200 \mathrm{~m}(\mathrm{M}-4)\end{array}$ & $\begin{array}{l}30 \sim 80 \mathrm{~m}(\mathrm{M}-5) ; \\
5 \sim 150 \mathrm{~m}(\mathrm{M}-6)\end{array}$ & $\geq 10 \mathrm{~m}$ \\
\hline Detection area & $0.5 \sim 5.0 \mathrm{~m} \times 2.8 \mathrm{~m}$ & $\begin{array}{l}100 \mathrm{~m} \times 20 \mathrm{~m}(\mathrm{M}-2) ; \\
13 \mathrm{~m} \times 3 \mathrm{~m}(\mathrm{M}-3) ; \\
150 \mathrm{~m} \times 50^{\circ}(\mathrm{M}-4)\end{array}$ & - & - \\
\hline $\begin{array}{l}\text { Vehicle speed for } \\
\text { detection }\end{array}$ & $10 \sim 100 \mathrm{~km} / \mathrm{h}$ & $10 \sim 100 \mathrm{~km} / \mathrm{h}$ & $10 \sim 80 \mathrm{~km} / \mathrm{h}$ \\
\hline Feature & $\begin{array}{l}\text { The time of two } \\
\text { sensors is used to } \\
\text { detect wrong-way } \\
\text { driving }\end{array}$ & $\begin{array}{l}24 \mathrm{GHz} \text { microwave Doppler } \\
\text { sensor }\end{array}$ & $\begin{array}{l}\text { Long detection range } \\
0 \sim 50 \mathrm{~km} / \mathrm{h}\end{array}$ & $\begin{array}{l}\text { Vehicle type detectable; } \\
\text { Sensor spacing } \\
\text { adjustable to reduce } \\
\text { possibility of wrong } \\
\text { detection }\end{array}$ \\
\hline $\begin{array}{l}\text { Objects that may } \\
\text { cause wrong } \\
\text { detection }\end{array}$ & $\begin{array}{l}\text { None } \\
\text { Song }\end{array}$ & $\begin{array}{l}\text { Moving objects detectable in } \\
\text { snow, rain and wind, etc; } \\
\text { Wrong detection with } \\
\text { parking vehicle and } \\
\text { signboard }\end{array}$ & $\begin{array}{l}\text { Light (sunlight, etc.); } \\
\text { Reflection of vehicle headlight } \\
\text { road lighting from road surface; } \\
\text { Moving shadow and swaying } \\
\text { tree; } \\
\text { Snow and rain }\end{array}$ & $\begin{array}{l}\text { Pedestrians and animals } \\
\text { like birds detectable; } \\
\text { Snow, rain and fog, etc., } \\
\text { detectable }\end{array}$ \\
\hline
\end{tabular}

Table 2 Installation of the roadside wrong-way warning systems and evaluation data collection.

\begin{tabular}{lllll}
\hline Sensor type & \# of makers & \# of locations & Data period & $\begin{array}{l}\text { Duration } \\
\text { (month) }\end{array}$ \\
\hline Ultrasonic & M-1 & 3 & $2008 / 8 \sim 2010 / 6$ & 23 \\
\hline & M-2 & 1 & $2008 / 9 \sim 2011 / 3$ & 31 \\
& & 1 & $2008 / 10 \sim 2011 / 3$ & 29 \\
& & 1 & $2008 / 11 \sim 2011 / 3$ & 28 \\
\hline Microwave Doppler & M-3 & 1 & $2008 / 7 \sim 2011 / 3$ & 32 \\
& & 1 & $2008 / 8 \sim 2011 / 3$ & 31 \\
\cline { 2 - 5 } & & 3 & $2008 / 9 \sim 2011 / 3$ & 30 \\
& M-4 & 1 & $2008 / 11 \sim 2011 / 3$ & 28 \\
& 1 & $2008 / 12 \sim 2011 / 3$ & 27 \\
\hline Image processing & M-5 & 1 & $2008 / 8 \sim 2011 / 3$ & 31 \\
\cline { 2 - 5 } & M-6 & 1 & $2008 / 9 \sim 2011 / 3$ & 30 \\
\hline Photoelectric & M-7 & 1 & $2008 / 7 \sim 2011 / 3$ & 32 \\
\hline
\end{tabular}

pass the double sensors. The microwave Doppler radar detects wrong-way vehicles and their speed by analyzing the microwaves reflected from the vehicles. The video image processing technology can also detect wrong-way vehicles and their speed by applying some image processing algorithm. Each type of sensor has its own particular characteristics and shortcomings which may lead to possible errors in detection. The objective of the paper is to evaluate, from the collected data, the roadside wrong-way warning systems of each sensor type. Table 2 shows the number of locations of the roadside wrong-way warning systems of each sensor type. Ultrasonic and photoelectric sensors were used each at three locations. Microwave Doppler sensor was applied at 12 locations and video image processing 
sensor at seven locations. All these systems were installed near the end of the off-ramp, so as to prevent the vehicles from entering the off-ramp from the rest area.

\section{Evaluation of the Roadside Wrong-Way Warning Systems}

\subsection{Data Analysis}

The data collected for evaluation is also shown in Table 2 for each type of sensor. The duration varies from 23 to 32 months depending on the time of system installment. The data comes from the output of the roadside wrong-way warning systems. It includes total traffic volume, number of wrong-way vehicles, the date and time the vehicles were detected going the wrong way. Once detected, two-minute video recordings, i.e., one minute each before and after the detection of wrong-way driving, are made. By checking the video recordings, it can be found out whether the detection is right or wrong. In addition, one can also judge if a vehicle going the wrong way stops, turns, and goes back the right way to the rest area, which means the system prevented wrong-way driving as expected. These data are used to calculate the following indices that are used to examine the detection accuracy and prevention effect of wrong-way driving by the systems:

- average number of vehicles detected of going the wrong way per month;

- average number of vehicles prevented from going the wrong way per month;

- wrong detection rate (average number of error detections of wrong-way driving per month);

- occurrence rate of wrong-way driving (average number of vehicles going the wrong way per month);

- prevention rate of wrong-way driving (number of vehicles prevented by the system from going the wrong way divided by number of vehicles going the wrong way).

\subsection{Wrong-Way Driving Incidents}

Table 3 shows the wrong-way occurrence rate per month in descending order that was detected by the roadside wrong-way warning systems. The number of wrong-way vehicles per month varies greatly from 0 to 83 , in which $88 \%(22 / 25)$ of the locations had less than four and only three locations had many wrong-way vehicles: 17.3 (No. 19), 48.6 (No. 22) and 82.7 (No. 8). It can be seen that the high occurrence rate of wrong-way driving incidents results from the following main causes:

- An off-ramp diverges at the end to different parking areas for passenger cars and heavy vehicles/motorcycles at the multistoried island rest area (No. 8);

- An exit ramp diverges from the off-ramp where some vehicles take the risk of going the wrong way and head to the exit or gas station through the off-ramp, after resting at the rest area (No. 10, 17-1, 17-2, 18 and 22);

- The on-ramp is located near the off-ramp or an ETC (electronic toll collection) exclusive exit and they are on the same side of a rest area (No. 3, 5, 9, 10, 14, 19 and 21);

- The location of the on- and off-ramps is irregular, and the access to the on-ramp can not be easily found by drivers (No. 13, 23 and 24).

Fig. 2 shows the plan view of the three locations, i.e., No. 8, 22 and 19, where the wrong-way occurrence rate is high.

\subsection{Evaluation of Roadside Wrong-Way Warning Systems with Different Types of Sensors}

Table 4 shows the wrong detection rate, the objects that may cause wrong detection and the actions that have been taken to improve detection by each sensor type. It can be seen from Table 4 that except for the ultrasonic sensor, which demonstrated a very low initial wrong detection rate, other three types of sensors (microwave Doppler, image processing and photoelectric) all showed a much higher wrong detection 
Table 3 Wrong-way occurrence rate at the 25 locations where the systems are installed.

\begin{tabular}{|c|c|c|c|c|c|}
\hline Location & Maker & $\begin{array}{l}\text { Year of } \\
\text { installation }\end{array}$ & $\begin{array}{l}\text { Data collection } \\
\text { period }\end{array}$ & $\begin{array}{l}\text { Wrong-way } \\
\text { occurrence rate } \\
(\# / \text { month })\end{array}$ & Remarks \\
\hline 8 & M-1 & $2008 / 8$ & 2008/8 2010/6 & 82.7 & $\begin{array}{l}\text { An off-ramp diverges at the end of off-ramp to different } \\
\text { parking areas for passenger cars and heavy } \\
\text { vehicles/motorcycles at the multistoried island rest area }\end{array}$ \\
\hline 22 & M-7 & $2008 / 8$ & $2008 / 8 \sim 2011 / 3$ & 48.6 & $\begin{array}{l}\text { An exit ramp diverges from the off-ramp where many } \\
\text { vehicles risk driving the wrong way to the exit through the } \\
\text { off-ramp after resting at the rest area }\end{array}$ \\
\hline 19 & M-4 & $2008 / 8$ & $2008 / 8 \sim 2011 / 3$ & 17.3 & $\begin{array}{l}\text { An ETC exclusive exit is located near the off-ramp to the } \\
\text { rest area and they are on the same side of the rest area }\end{array}$ \\
\hline 10 & M-3 & $2008 / 9$ & 2008/9 2011/3 & 3.8 & $\begin{array}{l}\text { The on- and off-ramps are located near and on the same } \\
\text { side of the rest area. Some vehicles take the risk of driving } \\
\text { the wrong way to a gas station located in the middle of the } \\
\text { off-ramp after resting at the rest area }\end{array}$ \\
\hline 3 & M-4 & $2008 / 9$ & $2008 / 9 \sim 2011 / 3$ & 2.9 & $\begin{array}{l}\text { An exit ramp diverges from the off-ramp where some } \\
\text { vehicles take the risk of driving the wrong way to the exit } \\
\text { through the off-ramp after resting at the rest area }\end{array}$ \\
\hline $17-2$ & M-6 & $2008 / 10$ & 2008/10 2011/3 & 2.5 & $\begin{array}{l}\text { An exit ramp diverges from the off-ramp where some } \\
\text { vehicles take the risk of driving the wrong way to the exit } \\
\text { through the off-ramp after resting at the rest area }\end{array}$ \\
\hline 21 & M-3 & $2008 / 9$ & 2008/9 2011/3 & 1.3 & $\begin{array}{l}\text { The on- and off-ramps are located near and on the same } \\
\text { side of the rest area }\end{array}$ \\
\hline 14 & M-3 & 2008/11 & 2008/11 2011/3 & 1.2 & $\begin{array}{l}\text { The on- and off-ramps are located near and on the same } \\
\text { side of the rest area }\end{array}$ \\
\hline $17-1$ & M-6 & $2008 / 10$ & 2008/10 2011/3 & 1.1 & $\begin{array}{l}\text { An exit ramp diverges from the off-ramp to the rest area } \\
\text { where some vehicles take the risk of driving the wrong way } \\
\text { to the exit through the off-ramp after resting at the rest area }\end{array}$ \\
\hline 5 & M-5 & $2008 / 8$ & $2008 / 8 \sim 2011 / 3$ & 1.0 & $\begin{array}{l}\text { The on- and off-ramps are located near and on the same } \\
\text { side of the rest area }\end{array}$ \\
\hline 23 & M-7 & $2008 / 8$ & 2008/8 2011/3 & 0.9 & $\begin{array}{l}\text { The location of the on- and off-ramps to the rest area is } \\
\text { irregular }\end{array}$ \\
\hline 4 & M-3 & $2008 / 12$ & $2008 / 12 \sim 2011 / 3$ & 0.5 & - \\
\hline 9 & M-1 & $2008 / 8$ & 2008/8 2010/6 & 0.4 & $\begin{array}{l}\text { The on- and off-ramps are located near and on the same } \\
\text { side of the rest area }\end{array}$ \\
\hline 18 & M-2 & $2008 / 10$ & 2008/10 2011/3 & 0.4 & $\begin{array}{l}\text { An exit ramp diverges from the off-ramp where some } \\
\text { vehicles take the risk of wrong-way driving to the exit } \\
\text { through the off-ramp after resting at the rest area }\end{array}$ \\
\hline 13 & M-3 & $2008 / 7$ & $2008 / 7 \sim 2011 / 3$ & 0.4 & The location of the on-ramps from the rest area is irregular \\
\hline 7 & M-3 & $2008 / 9$ & Sep. 2008 2011/3 & 0.3 & - \\
\hline 24 & M-7 & $2008 / 8$ & Aug. 2008 2011/3 & 0.3 & $\begin{array}{l}\text { The rest area is located far from the mainline. The location } \\
\text { of the on- and off-ramps to the rest area is irregular }\end{array}$ \\
\hline 6 & M-1 & $2008 / 8$ & $2008 / 8 \sim 2010 / 6$ & 0.2 & - \\
\hline 20 & M-3 & $2008 / 8$ & $2008 / 8 \sim 2011 / 3$ & 0.1 & - \\
\hline 1 & M-5 & $2008 / 7$ & $2008 / 7 \sim 2011 / 3$ & 0.1 & - \\
\hline 12 & M-6 & $2008 / 10$ & $2008 / 10 \sim 2011 / 3$ & 0.1 & - \\
\hline 16 & M-6 & $2008 / 7$ & $2008 / 7 \sim 2011 / 3$ & 0.1 & - \\
\hline 2 & M-2 & $2008 / 9$ & 2008/9 2011/3 & 0.0 & - \\
\hline 11 & M-2 & 2008/11 & $2008 / 11 \sim 2011 / 3$ & 0.0 & - \\
\hline 15 & M-6 & $2008 / 7$ & $2008 / 7 \sim 2011 / 3$ & 0.0 & - \\
\hline
\end{tabular}

rate caused by vehicles parked on shoulders, nearby signboards, lights (sunlight, vehicle headlight and road lighting), road surface reflections, pedestrians and bad weather conditions like snow and heavy rain.
After careful field adjustment, the final wrong detection rate for each sensor type decreased very much, to less than 10 wrong detections per month. The objects that may have caused wrong detections 
for microwave Doppler sensor were mainly vehicles parked on shoulders and signboards, and the actions taken to lower the number of wrong detections were adjustments of beam angle and detection area, or even replacing the sensors with those that have functions to adjust the detection range. For image processing sensor, the objects causing wrong detection were lights such as sunlight, vehicle headlights, and the reflection of headlight and road lighting on wet road surfaces, and snow, and it was needed to adjust the camera angle and/or detection area to reduce the wrong detections. For photoelectric sensor, pedestrians were the main cause of wrong detections and the action taken was to modify sensor spacing to correct wrong detections. The system developer M-4 of microwave Doppler sensor has not conducted a field adjustment because of some other reason, and thus was not considered in the evaluation of detection accuracy. It can be seen that in order to reduce the wrong detection rate, for each sensor type, one needs to carefully adjust the sensor angle and detection area, etc., at the phase of installment and also to re-adjust the sensors to improve their detection accuracy.

From the results of field trials in the study, Table 5 summarizes the detection accuracy, the objects that tend to cause wrong detections, possible actions that can be taken to improve detection accuracy as well as main features of each sensor type. The detection accuracy
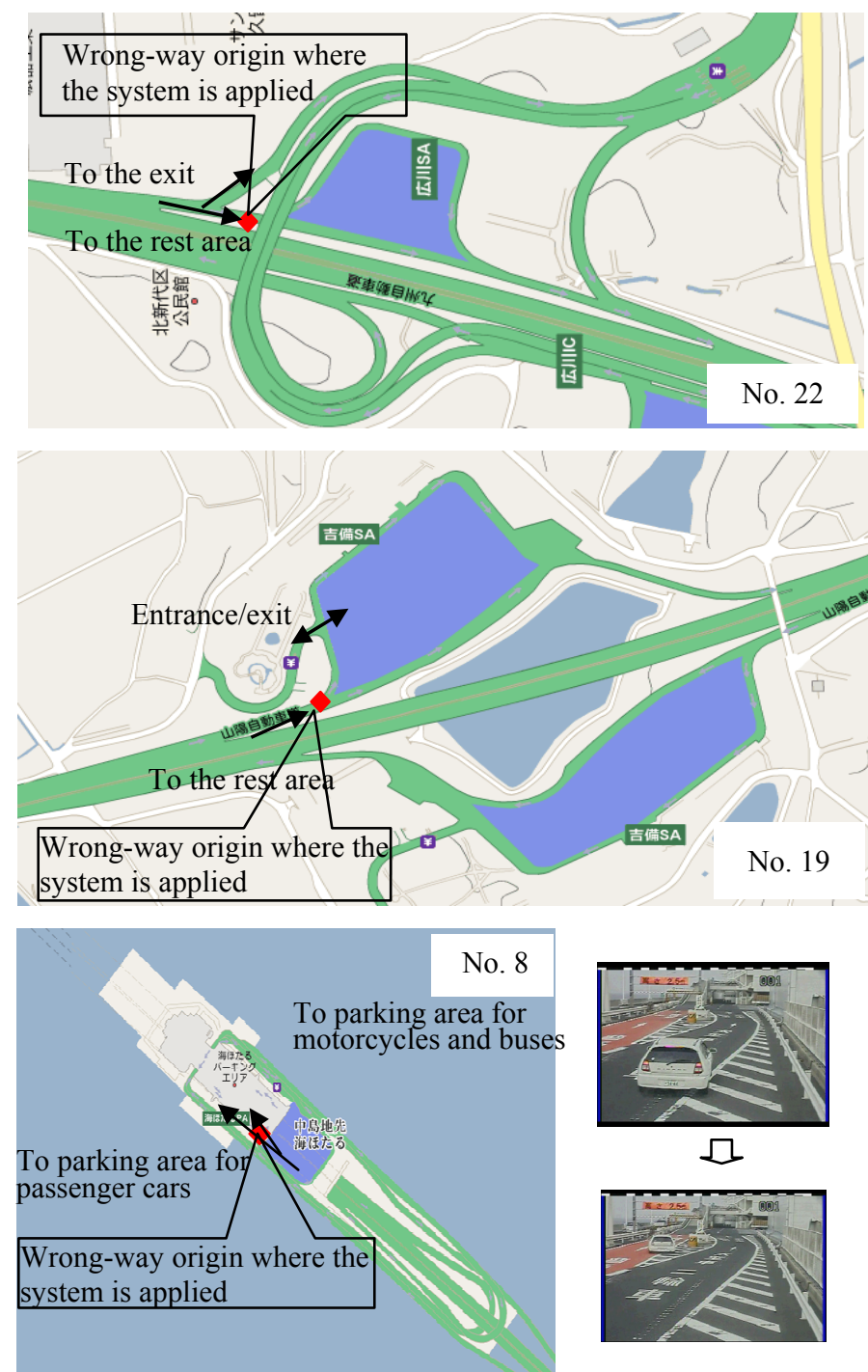

Fig. 2 Plan view of the three locations with high wrong-way occurrence rate. 
Table 4 Wrong detection and their improvement for each sensor type.

\begin{tabular}{|c|c|c|c|c|c|c|}
\hline \multirow[b]{2}{*}{ Sensor type } & \multirow[b]{2}{*}{ Maker } & \multicolumn{2}{|c|}{ Initial wrong detection } & \multirow[b]{2}{*}{ Actions taken } & \multicolumn{2}{|c|}{ Final wrong detection } \\
\hline & & \begin{tabular}{|l} 
Avg. \\
(min-max) \\
$\# /$ month \\
\end{tabular} & $\begin{array}{l}\text { Objects of wrong } \\
\text { detection }\end{array}$ & & \begin{tabular}{|l|} 
Avg. \\
(min-max) \\
$\# /$ month \\
\end{tabular} & $\begin{array}{l}\text { Objects of wrong } \\
\text { detection }\end{array}$ \\
\hline Ultrasonic sensor & M-1 & $\begin{array}{l}0.0 \\
(0.0 \sim 0.1)\end{array}$ & none & - & - & - \\
\hline \multirow{3}{*}{$\begin{array}{l}\text { Microwave Doppler } \\
\text { sensor }\end{array}$} & M-2 & $\begin{array}{l}0.2 \\
(0.0 \sim 0.5)\end{array}$ & none & - & - & - \\
\hline & M-3 & $\begin{array}{l}91.3 \\
(0.4 \sim 615)\end{array}$ & $\begin{array}{l}\text { Vehicles parked on } \\
\text { shoulders }\end{array}$ & $\begin{array}{l}\text { Adjusting beam angle and } \\
\text { detection area; } \\
\text { Replacing sensors with } \\
\text { detection range } \\
\text { adjustment function } \\
\end{array}$ & $\begin{array}{l}10.9 \\
(0.0 \sim 73)\end{array}$ & $\begin{array}{l}\text { Vehicles parked on } \\
\text { shoulders; } \\
\text { Heavy rain and } \\
\text { strong wind }\end{array}$ \\
\hline & M-4 & $\begin{array}{l}453 \\
(196 \sim 710)\end{array}$ & $\begin{array}{l}\text { Vehicles parked on } \\
\text { shoulders; } \\
\text { Signboard } \\
\end{array}$ & J & - & - \\
\hline \multirow[b]{2}{*}{$\begin{array}{l}\text { Video image } \\
\text { processing sensor }\end{array}$} & M-5 & $\begin{array}{l}63.3 \\
(5.0 \sim 121.5)\end{array}$ & $\begin{array}{l}\text { Lights (sunlight, vehicle } \\
\text { headlight, etc.); } \\
\text { Road surface reflection } \\
\text { (vehicle headlight, road } \\
\text { lighting, etc.) }\end{array}$ & Adjusting camera angle & $\begin{array}{l}3.9 \\
(2.8 \sim 5.0)\end{array}$ & $\begin{array}{l}\text { Snowstorm; } \\
\text { Insects and animals; } \\
\text { Road surface } \\
\text { reflection }\end{array}$ \\
\hline & M-6 & $\begin{array}{l}24.8 \\
(4.0 \sim 96.3)\end{array}$ & $\begin{array}{l}\text { Lights (sunlight, etc.); } \\
\text { Wet road surface } \\
\text { reflection (vehicle } \\
\text { headlight); } \\
\text { Snow }\end{array}$ & Adjusting detection area & $\begin{array}{l}7.5 \\
(4.0 \sim 19.0)\end{array}$ & $\begin{array}{l}\text { Lights (sunlight, } \\
\text { etc.); } \\
\text { Wet road surface } \\
\text { reflection (vehicle } \\
\text { headlight); } \\
\text { Snow } \\
\end{array}$ \\
\hline Photoelectric sensor & M-7 & $\begin{array}{l}5.9 \\
(2.3 \sim 8.3)\end{array}$ & Pedestrians, etc. & $\begin{array}{l}\text { Modifying sensor spacing } \\
\text { to correct wrong detection } \\
\text { of pedestrians }\end{array}$ & $\begin{array}{l}8.8 \\
(5.1 \sim 11.3)\end{array}$ & $\begin{array}{l}\text { Snow; } \\
\text { Pedestrians; } \\
\text { Insects and animals, } \\
\text { etc. }\end{array}$ \\
\hline
\end{tabular}

Table 5 Detection accuracy, subjects and main features for each sensor type.

\begin{tabular}{|c|c|c|c|c|}
\hline \multirow[b]{2}{*}{ Sensor type } & \multicolumn{3}{|c|}{ Detection accuracy } & \multirow[b]{2}{*}{ Feature } \\
\hline & $\begin{array}{l}\text { Wrong } \\
\text { detection rate } \\
(\text { Avg. } \\
\text { (min-max) } \\
\text { \#/month) } \\
\end{array}$ & Objects of wrong detection & $\begin{array}{l}\text { Actions and subjects for accuracy } \\
\text { improvement }\end{array}$ & \\
\hline Ultrasonic & $\begin{array}{l}0.0 \\
(0.0 \sim 0.1)\end{array}$ & none & - & Very high accuracy \\
\hline \multirow{2}{*}{$\begin{array}{l}\text { Microwave } \\
\text { Doppler }\end{array}$} & \multirow{2}{*}{$\mid \begin{array}{l}0.4 \\
(00 \sim 1.7)\end{array}$} & Vehicles parked on shoulders & $\begin{array}{l}\text { Sensor angle and detection area were } \\
\text { adjusted to avoid reflection of other } \\
\text { objects }\end{array}$ & \multirow{2}{*}{$\begin{array}{l}\text { High accuracy can be } \\
\text { attained after adjusting } \\
\text { sensor angle and } \\
\text { detection area to avoid } \\
\text { reflection of other objects }\end{array}$} \\
\hline & & Heavy rain and strong wind & $\begin{array}{l}\text { No actions were taken because frequency } \\
\text { was very low }\end{array}$ & \\
\hline \multirow{2}{*}{$\begin{array}{l}\text { Image } \\
\text { processing }\end{array}$} & \multirow{2}{*}{$\begin{array}{l}6.5 \\
(2.8 \sim 19.0)\end{array}$} & \begin{tabular}{|l|} 
Direct sunlight; \\
Reflection of sunlight, vehicle \\
headlight, road lighting, etc. \\
on (wet) road surface
\end{tabular} & $\begin{array}{l}\text { Camera angle and detection area were } \\
\text { adjusted to avoid incident light }\end{array}$ & \multirow{2}{*}{$\begin{array}{l}\text { Detection accuracy is } \\
\text { relatively low because } \\
\text { wrong detection occurs } \\
\text { easily in case of lights } \\
\text { and objects with } \\
\text { movement }\end{array}$} \\
\hline & & $\begin{array}{l}\text { Snow, rain, insects and } \\
\text { animals }\end{array}$ & $\begin{array}{l}\text { No actions were taken although } \\
\text { modification of image processing } \\
\text { algorithm could be effective to reduce } \\
\text { wrong detection }\end{array}$ & \\
\hline Photoelectric & $\begin{array}{l}8.8 \\
(5.1 \sim 11.3)\end{array}$ & $\begin{array}{l}\text { Snow, pedestrians, insects and } \\
\text { animals, etc.; } \\
\text { Other unidentified objects of } \\
\text { wrong detections }\end{array}$ & $\begin{array}{l}\text { Wrong detection was improved through } \\
\text { modification of sensor spacing for } \\
\text { pedestrians; } \\
\text { The cause of wrong detection needs to be } \\
\text { identified }\end{array}$ & $\begin{array}{l}\text { Detection accuracy is } \\
\text { relatively low because } \\
\text { there exist many } \\
\text { unidentified objects of } \\
\text { wrong detections }\end{array}$ \\
\hline
\end{tabular}


after fine adjustments in the field ranks highest for ultrasonic sensor with an average wrong detection rate of 0.0 per month with a range of $0.0 \sim 0.1$, and the second place is for microwave Doppler sensor at 0.4 $(0.0 \sim 1.7)$, followed by image processing sensor at 6.5 (2.8 19.0) and photoelectric sensor at 8.8 (5.1 11.3). Each sensor type has their weak points, but actions can be taken to lower the number of detection errors as shown in the Table 5. In addition, no fine adjustments were made in the study for bad weather conditions such as heavy rain, snow, strong wind, and insects and animals. It should be noted that the accuracy of detection was not compared through controlled experiments here in this study.

Each sensor type was installed at different sites by different system developers. Therefore, in order to accurately compare the detection accuracy for each sensor type, it is recommended that each sensor type be employed at the same site for a sufficient period.

\subsection{Prevention Effect of the Roadside Wrong-Way Warning Systems}

The effectiveness of the roadside wrong-way warning systems on preventing wrong-way driving is evaluated in the study by using the prevention rate of wrong-way driving which is defined as the number of vehicles prevented by the system from going the wrong way divided by the number of vehicles going the wrong way. The effectiveness is judged from the one minute video recordings of a car driving the wrong way and returning back to the rest area, which were recorded after detection activated the system. If a car driving the wrong way returns back to the rest area taking more than one minute after detection, it is not counted as a prevented wrong-way driving because it can not be told from the data collected if the car went back or just continued to go the wrong way.

Table 6 shows the prevention effect of the roadside wrong-way warning systems for altogether 16 locations where more than nine wrong-way vehicles were correctly detected by the systems in around
23 32 months. It describes the details of the systems such as sensor type, warning messages and display media (VMS or static signboard), and the distance between the sensor and display media, as well as the wrong-way occurrence rate and prevention rate per month. It is seen from Table 6 that the prevention effect varied greatly from $0 \%$ to $100 \%$, and, of the 16 locations, six systems yielded high prevention effect of more than $80 \%$ while seven systems had much lower effect of less than $20 \%$. Even for the same system developed by the same maker with the same sensor type, a completely different prevention effect is achieved at sites such as No. 22, No. 23 and No. 24. This means that in addition to the accuracy of the systems themselves, the prevention effect depends on site conditions where the systems are installed and periodical adjustment. Among the seven sites with a low prevention effect, it was difficult to achieve the desired prevention effect just by using the warning systems at the three lowest sites (No. 10, 17-2 and 22) and the fifth lowest site (No. 17-1) where an exit ramp diverges from the off-ramp, because many drivers were probably willing to take the risk of driving the wrong way to the exit through the off-ramp after resting at the rest area, ignoring the warning from the system. In such cases, enforcement should be carried out to prevent wrong-way driving that is done intentionally by drivers.

\subsection{Overall Evaluation of the Roadside Wrong-Way} Warning Systems

Table 7 is a summary of the overall evaluation of the roadside wrong-way warning systems with different types of sensors (ultrasonic/microwave Doppler/image processing/photoelectric) based on the evaluation results carried out in the study. Some of the performance indices are obtained from hearings of the system developers, and therefore, could be subjective to a certain extent. Among the four sensor types, ultrasonic and microwave Doppler sensors yield a much lower wrong detection rate than image processing 
Table 6 Prevention effect of the roadside wrong-way warning systems for locations of more than nine wrong-way vehicles in around $23 \sim 32$ months.

\begin{tabular}{|c|c|c|c|c|c|c|c|c|c|}
\hline Location & Maker & $\begin{array}{l}\text { Data collection } \\
\text { period }\end{array}$ & $\begin{array}{l}\text { Wrong-way } \\
\text { occurrence } \\
\text { rate } \\
\text { (\#/month) }\end{array}$ & $\begin{array}{l}\text { Prevention } \\
\text { rate }\end{array}$ & Sensor type & $\begin{array}{l}\text { Warning message } \\
\text { display media }\end{array}$ & Warning message & $\begin{array}{l}\text { Spacing } b / t \\
\text { sensor and } \\
\text { display }\end{array}$ & Remarks \\
\hline 24 & M-7 & 2008/8 2011/3 & 0.3 & $100 \%$ & Photoelectric & $\begin{array}{l}\text { Static signboard, } \\
\text { revolving lamp, flash } \\
\text { light }\end{array}$ & $\begin{array}{l}\text { Wrong-way! } \\
\text { Dangerous! }\end{array}$ & $46 \mathrm{~m}$ & $\begin{array}{l}\text { The rest area is located far from the mainline } \\
\text { The location of the on- and off-ramps to the } \\
\text { rest area is irregular }\end{array}$ \\
\hline 8 & M-1 & 2008/8 2010/6 & 82.7 & $100 \%$ & Ultrasonic & VMS, warning sound & $\begin{array}{l}\text { Dangerous! Go back! } \\
\text { Wrong way } \\
\text { prohibited! } \\
\text { (alternative display) }\end{array}$ & $64 \mathrm{~m}$ & $\begin{array}{l}\text { An off-ramp diverges at the end of off-ramp } \\
\text { to different parking areas for passenger cars } \\
\text { and heavy vehicles/motorcycles at the } \\
\text { multistoried island rest area }\end{array}$ \\
\hline 19 & M-4 & 2008/8 2011/3 & 17.3 & $99 \%$ & $\begin{array}{l}\text { Microwave } \\
\text { Doppler }\end{array}$ & $\begin{array}{l}\text { VMS, red revolving } \\
\text { lamp }\end{array}$ & $\begin{array}{l}\text { Wrong-way driving! } \\
\text { No entering! } \\
\text { (alternative display) }\end{array}$ & $40 \mathrm{~m}$ & $\begin{array}{l}\text { An ETC exclusive exit is located near the } \\
\text { off-ramp to the rest area and they are on the } \\
\text { same side of the rest area }\end{array}$ \\
\hline 5 & M-5 & $2008 / 8 \sim 2011 / 3$ & 1.0 & $94 \%$ & $\begin{array}{l}\text { Image } \\
\text { processing }\end{array}$ & VMS & $\begin{array}{l}\text { Wrong way } \\
\text { prohibited! }\end{array}$ & $50 \mathrm{~m}$ & $\begin{array}{l}\text { The on- and off-ramps are located near and } \\
\text { on the same side of the rest area }\end{array}$ \\
\hline 23 & M-7 & 2008/8 2011/3 & 0.9 & $84 \%$ & Photoelectric & $\begin{array}{l}\text { Static signboard, } \\
\text { revolving lamp, flash } \\
\text { light }\end{array}$ & $\begin{array}{l}\text { Wrong-way! } \\
\text { Dangerous! }\end{array}$ & $40 \mathrm{~m}$ & $\begin{array}{l}\text { The location of the on- and off-ramps to the } \\
\text { rest area is irregular }\end{array}$ \\
\hline 3 & M-4 & 2008/9 2011/3 & 2.9 & $79 \%$ & $\begin{array}{l}\text { Microwave } \\
\text { Doppler }\end{array}$ & $\begin{array}{l}\text { VMS, red revolving } \\
\text { lamp }\end{array}$ & $\begin{array}{l}\text { Wrong-way driving! } \\
\text { No entering! } \\
\text { (alternative display) }\end{array}$ & $20 \mathrm{~m}$ & $\begin{array}{l}\text { An exit ramp diverges from the off-ramp } \\
\text { where some vehicles take the risk of driving } \\
\text { the wrong way to the exit through the } \\
\text { off-ramp after resting at the rest area }\end{array}$ \\
\hline 21 & M-3 & 2008/8 2011/3 & 1.3 & $59 \%$ & $\begin{array}{l}\text { Microwave } \\
\text { Doppler }\end{array}$ & $\begin{array}{l}\text { VMS, yellow revolving } \\
\text { lamp, warning sound }\end{array}$ & Dangerous! Go back! & $20 \mathrm{~m}$ & $\begin{array}{l}\text { The on- and off-ramps are located near and } \\
\text { on the same side of the rest area }\end{array}$ \\
\hline 9 & M-1 & 2008/8 2010/6 & 0.4 & $56 \%$ & Ultrasonic & VMS, warning sound & $\begin{array}{l}\text { Wrong way } \\
\text { prohibited! }\end{array}$ & $48 \mathrm{~m}$ & $\begin{array}{l}\text { The on- and off-ramps are located near and } \\
\text { on the same side of the rest area }\end{array}$ \\
\hline 14 & M-3 & 2008/11 2011/3 & 1.2 & $21 \%$ & $\begin{array}{l}\text { Microwave } \\
\text { Doppler }\end{array}$ & $\begin{array}{l}\text { VMS, yellow revolving } \\
\text { lamp, warning sound }\end{array}$ & Dangerous! Go back! & $20 \mathrm{~m}$ & $\begin{array}{l}\text { The on- and off-ramps are located near and } \\
\text { on the same side of the rest area. }\end{array}$ \\
\hline 4 & M-3 & $2008 / 12 \sim 2011 / 3$ & 0.5 & $15 \%$ & $\begin{array}{l}\text { Microwave } \\
\text { Doppler }\end{array}$ & $\begin{array}{l}\text { VMS, yellow revolving } \\
\text { lamp, warning sound }\end{array}$ & Dangerous! Go back! & $30 \mathrm{~m}$ & $\begin{array}{l}\text { The on- and off-ramps are located near and } \\
\text { on the same side of the rest area }\end{array}$ \\
\hline $17-1$ & M-6 & $2008 / 10 \sim 2011 / 3$ & 1.1 & $11 \%$ & $\begin{array}{l}\text { Image } \\
\text { processing }\end{array}$ & $\begin{array}{l}\text { VMS (horizontal and } \\
\text { vertical) }\end{array}$ & $\begin{array}{l}\text { Wrong way } \\
\text { prohibited! }\end{array}$ & $50 \mathrm{~m}$ & $\begin{array}{l}\text { An exit ramp diverges from the off-ramp to } \\
\text { the rest area where some vehicles take the } \\
\text { risk of driving the wrong way to the exit } \\
\text { through the off-ramp after resting at the rest } \\
\text { area }\end{array}$ \\
\hline 13 & M-3 & 2008/7 2011/3 & 0.4 & $10 \%$ & $\begin{array}{l}\text { Microwave } \\
\text { Doppler }\end{array}$ & $\begin{array}{l}\text { VMS, yellow revolving } \\
\text { lamp, warning sound }\end{array}$ & Dangerous! Go back! & $60 \mathrm{~m}$ & $\begin{array}{l}\text { The location of the on-ramps from the rest } \\
\text { area is irregular }\end{array}$ \\
\hline
\end{tabular}




\begin{tabular}{|c|c|c|c|c|c|c|c|c|c|}
\hline Location & Maker & $\begin{array}{l}\text { Data collection } \\
\text { period }\end{array}$ & $\begin{array}{l}\text { Wrong-way } \\
\text { occurrence } \\
\text { rate } \\
(\# / \text { month })\end{array}$ & $\begin{array}{l}\text { Prevention } \\
\text { rate }\end{array}$ & Sensor type & $\begin{array}{l}\text { Warning message } \\
\text { display media }\end{array}$ & Warning message & \begin{tabular}{l|} 
Spacing \\
$\mathrm{b} / \mathrm{t}$ sensor \\
and \\
display
\end{tabular} & Remarks \\
\hline $17-2$ & M-6 & $2008 / 10 \sim 2011 / 3$ & 2.5 & $7 \%$ & $\begin{array}{l}\text { Image } \\
\text { processing }\end{array}$ & $\begin{array}{l}\text { VMS (horizontal and } \\
\text { vertical) }\end{array}$ & $\begin{array}{l}\text { Wrong way } \\
\text { prohibited! }\end{array}$ & $40 \mathrm{~m}$ & $\begin{array}{l}\text { An exit ramp diverges from the off-ramp where } \\
\text { some vehicles take the risk of driving the wrong } \\
\text { way to the exit through the off-ramp after resting at } \\
\text { the rest area }\end{array}$ \\
\hline 22 & M-7 & $2008 / 8 \sim 2011 / 3$ & 48.6 & $1 \%$ & Photoelectric & $\begin{array}{lr}\text { Static } & \text { signboard, } \\
\text { revolving } & \text { lamp, flash } \\
\text { light } & \end{array}$ & $\begin{array}{l}\text { Wrong-way! } \\
\text { Dangerous! }\end{array}$ & $37 \mathrm{~m}$ & $\begin{array}{l}\text { An exit ramp diverges from the off-ramp where } \\
\text { many vehicles risk driving the wrong way to the } \\
\text { exit through the off-ramp after resting at the rest } \\
\text { area }\end{array}$ \\
\hline
\end{tabular}

Table 7 Summary of the overall evaluation of the roadside wrong-way warning systems.

\begin{tabular}{|c|c|c|c|c|c|}
\hline \multicolumn{2}{|l|}{ Sensor type } & Ultrasonic & Microwave Doppler & Image processing & Photoelectric \\
\hline \multicolumn{2}{|l|}{$\begin{array}{l}\text { Detection accuracy } \\
\text { (wrong detection/month) }\end{array}$} & $\begin{array}{l} \\
0.1(0.0 \sim 0.1)\end{array}$ & $\begin{array}{l} \\
0.4(0.0 \sim 1.7)\end{array}$ & $\begin{array}{l}\Delta \\
6.5(2.8 \sim 19.0)\end{array}$ & $\begin{array}{l}\Delta \\
8.8(5.1 \sim 11.3) \\
\end{array}$ \\
\hline \multirow{5}{*}{$\begin{array}{l}\text { Objects that may cause } \\
\text { wrong detection }\end{array}$} & Rain and snow, etc. & - & $\mathrm{X}$ & $\mathrm{X}$ & $\mathrm{X}$ \\
\hline & Sunlight and tail lamp, etc. & - & O & $\mathrm{X}$ & O \\
\hline & Birds and animals, etc. & - & $\mathrm{X}$ & $\mathrm{X}$ & $\mathrm{X}$ \\
\hline & Reflection from obstacles & - & $\mathrm{X}$ & $\mathrm{X}$ & O \\
\hline & Reflection from road surface & - & O & $\mathrm{X}$ & O \\
\hline Cost & Initial (million USD/location) & $4.0 \sim 5.0$ & $4.5 \sim 6.0$ & $6.6 \sim 7.3$ & 1.5 \\
\hline \multicolumn{2}{|c|}{ Detection applied on road of two lanes or more } & $\mathrm{X}$ & $\mathrm{X}$ & $\triangle$ & $\Delta$ \\
\hline \multicolumn{2}{|l|}{ Durability } & $\begin{array}{l}\bigcirc \\
5 \sim 10 \text { years }\end{array}$ & $\begin{array}{l}\bigcirc \\
5 \sim 10 \text { years }\end{array}$ & $\begin{array}{l}0 \\
6 \text { years }\end{array}$ & $\begin{array}{l}\Delta \\
3 \sim 15 \text { years } \\
\text { (fan-3 years, power- } 7 \text { years, } \\
\text { breaker- } 15 \text { years) }\end{array}$ \\
\hline \multicolumn{2}{|c|}{ Prevention rate of wrong-way driving* } & $\begin{array}{l}\triangle \\
78 \%(56 \% \sim 100 \%)\end{array}$ & $\begin{array}{l}\mathrm{X} \\
47 \%(10 \% \sim 99 \%)\end{array}$ & $\begin{array}{l}\mathrm{O} \\
94 \%\end{array}$ & $\begin{array}{l}\text { O } \\
92 \%(84 \% \sim 100 \%)\end{array}$ \\
\hline
\end{tabular}

Note: $O$ : good; $\triangle$ : fair; $\mathrm{X}$ : poor.

*The prevention effect is not included here for those sites where wrong-way driving is done intentionally by drivers. 
and photoelectric sensors. On the contrary, image processing and photoelectric sensors demonstrate a high effect on the prevention of wrong-way driving and ultrasonic sensor seems also satisfactory. Microwave Doppler sensor, however, does not show a stable prevention effect. In terms of cost, the photoelectric sensor is much cheaper compared to the other three. It is difficult, however, for ultrasonic and microwave Doppler sensors to be applied for multi-lane sections on motorways. There seems to be no distinct difference in durability. All the systems, whichever sensor type is applied, need periodical inspection and fine adjustment in order to keep the high performance of the systems.

\section{Conclusions}

This paper describes an evaluation of roadside wrong-way warning systems with four different types of sensors that have been applied as first trials at 24 rest areas on motorways in Japan since 2008. The systems were installed to detect and warn wrong-way drivers at off-ramps leading from the mainline to rest areas, and the evaluation was made from the viewpoint of detection accuracy and their effects on preventing wrong-way driving. The sensing technology includes microwave Doppler radar, ultrasonic sensor, photoelectric sensor and video image processing technology.

It is found from the evaluation results that wrong-way driving incidents occur because:

- An exit or another off-ramp diverges from an off-ramp before entering the rest area so that some drivers dare to take the risk of driving the wrong way to the exit on the off-ramp after resting at the rest area;

- The on-ramp is located near the off-ramp or an ETC exclusive exit and they are on the same side of the rest area;

- Access to the on-ramp can not be easily found because drivers are not familiar with the locations of the on- and off-ramps.

The detection accuracy ranks the highest for ultrasonic and microwave Doppler sensors. Image processing and photoelectric sensors demonstrate a high effect to prevent wrong-way driving. The ultrasonic sensor seems to be satisfactory in the prevention of wrong-way driving. The microwave Doppler sensor, however, does not seem to show a stable prevention effect. In order to improve the detection error rate, it is important that the sensor angle, detection area, etc., for each sensor type should be carefully adjusted at installment and also be re-adjusted periodically to improve their detection accuracy. The roadside wrong-way warning systems are only effective for unintentional wrong-way driving. For intentional wrong-way driving, however, enforcement is recommended to stop such acts.

Considering Japanese severe aging society now and in the near future, wrong-way warning systems that apply advanced ITS technologies are important to alert drivers and to effectively prevent wrong-way driving on auto-only highways and motorways. In this respect, the roadside wrong-way warning systems described and evaluated in the study need to be improved in terms of detection accuracy and prevention effect. Development of sensors with high accuracy is crucial and inevitable.

\section{References}

[1] Cooner, S. A., Cothron, A. S., and Ranft, S. E. 2004. Countermeasures for Wrong-Way Movement on Freeways: Overview of Project Activities and Findings. Report No. FHWA (Federal Highway Administration)/TX-04/4128-1, Texas Transportation Institute, the Texas A\&M University System.

[2] Cooner, S. A., and Ranft, S. E. 2008. "Wrong-Way Driving on Freeways: Problems, Issues and Countermeasures." Presented at the 2008 Annual Meeting of the Transportation Research Board, Washington, D. C., USA.

[3] National Transportation Safety Board. 2012. Wong-Way Driving. Highway special investigation report.

[4] Zhou, H., Zhao, J., Fries, R., Gahrooei, M., Wang, L., and Vaughn, B. 2012. Investigation of Contributing Factors Regarding Wrong-Way Driving on Freeways. Illinois Center for Transportation Series No. 12-010. 
[5] Zhou, H., Zhao, J., Fries, R., and Rouhalamin, M. 2014. "Statistical Characteristics of Wrong-Way Driving Crashes on Illinois Freeways." Presented at the 2014 TRB (Transportation Research Board) Annual Meeting, Washington, D. C., USA.

[6] Scaramuzza, G., and Cavegn, M. 2007. "Wrong-Way Drivers: Extent-Interventions." Presented at the 2007 European Transport Conference, Noordwijkerhout, The Netherlands.

[7] Xing, J. 2015. "Characteristics of Wrong-Way Driving on Motorways in Japan.” IET Intelligent Transport Systems 9 (1): 3-11.

[8] Tatsumi, M., and Adachi, T. 2010. "Countermeasures Against Traffic Accidents by Wrong-Way Driving." Presented at 17th ITS (Intelligent Transportation Systems)
World Congress, Busan, South Korea.

[9] Topolsek, M. 2007. "Prevention of Wrong-Way Driving on Freeways.” Promet-Traffic \& Transportation 19 (5): 311-21.

[10] Vaswani, H. 1977. "Virginia's Crash Program to Reduce Wrong-Way Driving." Transportation Research Record 644: 87-90.

[11] Forthoffer, M., Bouzar, S., Lenoir, F., Blosseville, J., and Aubert, D. 1996. "Automatic Incident Detection: Wrong-Way Vehicle Detection Using Image Processing." Presented at the 3rd World Congress on Intelligent Transportation Systems, Orlando, Florida, USA.

[12] Olivier, F., and Contremoulins, P. 2012. "Anti-driving Wrong Way Device of Maison-Brulee on the A13 Motorway." Revue Generale des Routes 812: 82-4. 